\title{
Efficient lignin decomposing microbial consortium to hasten rice- straw composting with moderate GHGs fluxes
}

Pradeep Kumar Dash

ICAR-National Rice Research Institute

Soumya Ranjan Padhy

ICAR-National Rice Research Institute

Pratap Bhattacharyya ( $\sim$ pratap162001@gmail.com )

National Rice Research Institute https://orcid.org/0000-0003-4007-4357

Ankita Pattanayak

ICAR-National Rice Research Institute

Soumya Routray

ICAR-National Rice Research Institute

Periyasamy Panneerselvam

ICAR-National Rice Research Institute

Amaresh Kumar Nayak

ICAR-National Rice Research Institute

Himanshu Pathak

National Institute of Abiotic Stress Management

\section{Research Article}

Keywords: Lignin degrading microbes, rice straw-burning, microbial-consortium, composting, enzymatic activities, GHGs fluxes

Posted Date: February 24th, 2021

DOI: https://doi.org/10.21203/rs.3.rs-203292/v1

License: @ (1) This work is licensed under a Creative Commons Attribution 4.0 International License. Read Full License

Version of Record: A version of this preprint was published at Waste and Biomass Valorization on June 30th, 2021. See the published version at https://doi.org/10.1007/s12649-021-01508-9. 


\section{Abstract}

We hypothised that lignin decomposition microbial consortium would make rice-straw decomposition faster as straw contain around 15-24\% lignin. In this study, we isolated lignin degrading microbes from four natural sources and based on their ability towards lignin degradation four microbial strains and their combination (2 bacteria (LB 8, LB 18) and 2 fungi (LF 3, LF 9) were selected for rice straw decomposition. During straw decomposition greenhouse gases emission, enzymatic activities ( $\beta$-glucosidase, cellulase, laccase), reduction in lignin content, weight loss and carbon nitrogen ratio $(\mathrm{C}: \mathrm{N})$ were quantified. The $\beta$-glucosidase, cellulase and laccase activities were higher in LB $18+$ LF 3 consortium as compared to others. The lignin content was also decreased (8.9-9.5 to 6.6-7.9\%) continuously from initial to 28 th days of composting under LB $18+$ LF 3 . We found the microbial consortium LB $18+$ LF 3 decomposed the rice straw faster as indicated by reduction of $\mathrm{C}: \mathrm{N}$ ratio and reduction of lignin, hemicellulose and cellulose contents of $60,19.2,41.5$ and $10.3 \%$, respectively at 28th day from initial compare to other strains/consortium. However, higher, $\mathrm{CH}_{4}$ and $\mathrm{CO}_{2}$ fluxes were observed at 28th days after composting ( 1.36 and $200.7 \mathrm{mg} \mathrm{m}^{-2} \mathrm{~h}^{-1}$ ) with no significant trend in $\mathrm{N}_{2} \mathrm{O}$ flux. Further, the consortium identified could be tested for in-situ straw decomposition with proper moisture management to evaluate its potential in field condition. Therefore, we conclude that use of lignin decomposing microbial consortium has the potential to hasten the composting of rice straw in large scale, so viable option to reduce the menace of straw burning.

\section{Introduction}

India is the global prime producer of rice (Oryza sativa) accounting for about $20 \%$ of world rice production. In India $43.2 \mathrm{~m}$ ha of area is under rice cultivation. The main byproducts of rice are straw, rice husk and rice bran. Approximately, 760 million tons of rice straw produced per year globally which is the 1.5 times greater than per ton of rice-grain production (FAO 2017; Satlewal et al. 2018). The disposal of this surplus straw creates a major concern now a day in all the rice growing areas (Borah et al. 2016). Moreover, since last two decades farmers prefer to burn this straw to clear the field for the timely sowing of wheat in northern and north-western parts of India. Open field-burning of straw release a large amount of pollutants including methane and fine/ inhalable particles, toxic gases such as carbon monoxide (CO), carcinogenic polycyclic aromatic hydrocarbons and volatile organic compounds (VOCs) (Tipayarom and Oanh, 2007) which are responsible for various environmental pollution and human health hazards. Burning of rice straw emits 0.7- $4.1 \mathrm{~g}$ of $\mathrm{CH}_{4}$ and $0.019-0.057 \mathrm{~g}$ of $\mathrm{N}_{2} \mathrm{O}$ per kg of dry rice straw and other gaseous pollutants such as $\mathrm{SO}_{2}, \mathrm{NOx}, \mathrm{HCl}$, and to some extent, dioxins and furans (Oanh et al. 2011).

Rice straw is carbohydrate polymers with heterogeneous complexes. It is a lignocellulosic material which consists of three major biochemical compounds like, cellulose, hemicellulose and lignin. Cellulose is composed of glucose units, which are linked together by

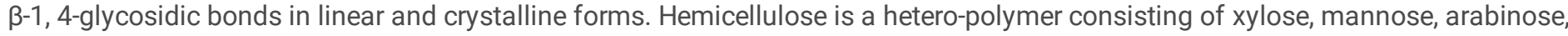
galactose and glucose in short and highly branched chain. Lignin is made of the structurally complex-carbohydrate, consisting of various bio-chemically stable linkages having high molecular weight (Gupta et al. 2016). After cellulose, lignin is the second most abundant renewable biopolymer in nature. And it is also the most abundant aromatic polymer in the biosphere (Rahman et al. 2013).

Ex-situ rice straw composting is a good option in India to tackle the issues like straw-burning and soil health management simultaneously. The main bottle-neck of rice straw decomposition both in in-situ and ex-situ condition is higher lignin content (5-24\%) takes more time for straw composting (Garrote et al. 2002). Therefore, microbes originally from natural sources and with higher lignin decomposing potential are an environment friendly and economic option for large-scale straw decomposition. Further, it is well known that the microbes produce higher ligninolytic enzymes that hasten the rice-straw composting. However, enzymes which degrading lignin are extra-cellular in nature and lignin having structurally heterogeneous and chemically more complex that cannot enter the cell for intracellular action (Rahman et al. 2013). Ligno-cellulolytic enzymes have substantial applications in various industries including chemicals, brewery and wine, food, fuel, textile and laundry, animal feed, paper-pulp and also in agriculture (Howard et al. 2003).

Decomposition of rice straw brings much needed organic manure to the soils that improves soil fertility as well as productivity. Incorporation of rice straw directly to the soil is certainly associated with immobilization of plant nutrients. High $\mathrm{C}$ : $\mathrm{N}$ ratio of straw and having considerable amount of silica, lignin make it difficult to decompose. Therefore, farmers favour in-situ burning of rice straw in the field causes great nutrient and economic losses. Rice straw burning also causes serious environmental problems which emits aerosols and greenhouse gases (Chang et al. 2013).

In our study we focused on the isolation of lignin degrading microbial isolates from natural lignin rich sources, such as elephant dung, dead plant-bark, vermicomposting pits and compost pits. After that most efficient bacterial and fungal strains as well as their

Page 2/19 
respective consortium were evaluated for rice straw composting. Therefore, objective of our study was to use the efficient lignin degrading microbial strains for rice straw decomposition in shorter time in eco-friendly manner.

\section{Materials And Methods}

\subsection{Isolation and selection of efficient lignin decomposing microbial consortium}

\subsubsection{Sample collection}

The samples were collected from four natural lignocellulosic sources like, elephant dung, dead plant-bark, vermicomposting pits and compost pits. The samples were collected in sterilized polythene bags and transported to the laboratory and immediately stored in refrigerator at $4^{\circ} \mathrm{C}$.

\subsubsection{Alkali lignin extraction}

The lignin was extracted from the bark of the woody plant as described by Howard et al. (2003). The bark used for extraction of lignin was dried and grinded to powder and $10 \mathrm{~g}$ of powdered bark was taken in a beaker and $5 \mathrm{~mL}$ of $1 \%$ sulfuric acid was added to it. Then, it was heated in hot air oven at $80^{\circ} \mathrm{C}$ for 20 minutes. After heating, $100 \mathrm{~mL}$ of $4 \%$ sodium hydroxide was added and the suspension was boiled for 30 minutes. The dark brown colored alkali lignin was thus obtained, then it was filtered and autoclaved at $15 \mathrm{lbs}$ for 10 min (Sasikumar et al. 2014). After autoclave, this soluble lignin was used as the selective media for isolation of lignin degrading bacteria.

\subsubsection{Isolation of lignin degrading bacteria and fungus}

The lignin degrading bacteria and fungus were isolated by using nutrient agar medium (NA) and potato dextrose agar (PDA), respectively in which lignin provided the sole carbon and energy source. In the medium, $1 \%$ alkaline lignin was added before autoclaving. Serial diluted collected samples were spreaded in respective media for lignin degrading bacteria and fungus from different sources. The bacterial plates were incubated at $37^{\circ} \mathrm{C}$ for $24 \mathrm{hrs}$, whereas the fungal plates at $30^{\circ} \mathrm{C}$ for $48 \mathrm{hrs}$ until colonies were developed. After incubation the colony forming units (CFU) were counted. These isolated bacteria and fungus of different morphology and characters were plated onto fresh nutrient agar (NA) and potato dextrose agar (PDA), respectively to obtain pure cultures (Rahman et al. 2013).

\subsubsection{Lignolytic activity of isolated microbes}

The microbial isolates were transferred to plats having methylene blue dye as an indicator for further screening. The microbes possess lignolytic enzymes undergoes oxidation of indicator dye. The isolated bacteria and fungus were streaked on methylene blue indicator dye $\left(0.25 \mathrm{~g} \mathrm{~L}^{-1}\right)$ containing NA and PDA plates. The plates were incubated and placed under observation daily for growth and decolorization zone (Bondounas et al., 2011). The decolorized microbial colonies were processed for identification.

\subsubsection{Efficiency test of the isolates}

The efficiency test of the bacterial and fungal isolates to utilize lignin-substrate was performed in minimal salt media containing lignin (MSM-L). The MSM-L consisted of $1 \%$ alkaline-lignin minimum salt medium solution $\left(\mathrm{K}_{2} \mathrm{HPO}_{4}-4.55 \mathrm{~g} ; \mathrm{KH}_{2} \mathrm{PO}_{4}-0.53 \mathrm{~g} ; \mathrm{MgSO}_{4}-0.5 \mathrm{~g}\right.$; $\mathrm{NH}_{4} \mathrm{NO}_{3}-5 \mathrm{ml}$ in 1 litre deionized water) (Chandra et al. 2007). The isolates were inoculated in $50 \mathrm{~mL}$ broth and placed in shaker. Dinitrosalicylic acid solution (Ingredients, g L-1; Di-nitrosalicylic Acid- 10 ml; Phenol- 2.0 ml; Sodium Sulphite- 0.5g; Rochelle salt (Potassium sodium tartarate) - 200g) was used for estimating reducing sugar. The glucose standard solution was prepared for this. The $2 \mathrm{~mL}$ of culture solution was taken from each conical flask and was transferred to test tubes and then $3 \mathrm{ml}$ of DNS solution and distilled water was added to each test tube and made up the volume to $10 \mathrm{ml}$. After that test tubes were heated 5 minutes in water bath and cooled down then the absorbance was taken at 540nm.

\subsubsection{Identification of lignin degrading bacteria}

Molecular identification of the efficient lignin degrading bacterial and fungal isolates were done by polymerase chain reaction (PCR) amplification of 16S rDNA and 18S rDNA, respectively. Amplified DNA were purified using a DNA purification kit (Promega, Madison, WI), and di-deoxy chain termination method was used for individual nucleotide sequences. The forward and reverse DNA sequences of 
each were confirmed and compared by using database Basic Local Alignment Search Tool (BLAST)

(http://www.ncbi.nlm.nih.gov/BLAST/).

\subsubsection{Preparation of consortium followed by compatibility test}

The most efficient two bacterial (LB 8, LB 18 (MN784664 \& MN784667)) and two fungal (LF 3, LF 9 (MK855473 \& MK855476)) strains were selected for rice straw decomposition. For preparing the consortium, at first compatibility test of selected microorganisms were done, because incompatibility of the co-isolates may also inhibit the growth of each other. After compatibility test, the bacterial and fungal isolates were inoculated into autoclaved nutrient broth (NB) and potato dextrose broth (PDB) separately. Then bacterial culture was incubated at $37^{\circ} \mathrm{C}$ for $24 \mathrm{hrs}$ whereas, fungal culture at $30^{\circ} \mathrm{C}$ for $48 \mathrm{hrs}$. After incubation, consortiums were prepared by addition of both bacterial and fungal broth. The bacteria and fungus strains alone and their respective consortium were taken for composting of rice straw.

\subsection{Evaluation of straw decomposition capabilities of the microbial consortium}

An experiment was conducted to study the efficacy of the isolated strains of bacteria, fungus and their consortium for decomposition of rice straw. In this experiment, 27 numbers of $10 \mathrm{~kg}$ capacity pots ( 9 treatments $\times 3$ replications) were taken. Nine treatments included 2 bacteria; 2 fungi; four bacteria-fungi consortium and one control (no microbial strain) were imposed in the experiment. In each pot $600 \mathrm{gm}$ of oven dried rice straw $(2-3 \mathrm{~cm}$ size) were added. Then all the microbial broth with consortium was inoculated to different pots having straw. Optimum moisture content was maintained during the decomposition process (15-20\%). The samples were collected during straw decomposition from different treatments at seven days interval for estimating the enzymatic activities ( $\beta$ glucosidase, cellulase, laccase), lignin contents, C: $\mathrm{N}$ ratio and weight loss.

\subsection{1 $\beta$-glucosidase activities}

The $\beta$-glucosidase activities was estimated based on the released by the detection of $p$-nitrophenol (PNP) from p-nitro phenyl- $\beta$-Dglucopyranoside (PNG, $0.05 \mathrm{M}$ ) as substrate (Eivazi and Tabatabai, 1988). Briefly, $1 \mathrm{~g}$ of sample from different treatments were added with $0.25 \mathrm{~mL}$ of toluene, $4 \mathrm{~mL}$ of MUB buffer ( $\mathrm{pH}-6.5$ ) and $1 \mathrm{~mL}$ of PNG solution and mixed with in a $50 \mathrm{~mL}$ Erlenmeyer flask. Then flasks were mixed properly, stoppered and incubated for 1 hour at $37^{\circ} \mathrm{C}$. After that, $1 \mathrm{~mL}$ of $0.5 \mathrm{M} \mathrm{CaCl}_{2}$ was added and trishydroxymethyl amino methane (THAM) was added stop the reaction. Flasks were swirled for few second and the suspension was filtered through Whatman no. 41. The concentrations of the filtrates were measured at $420 \mathrm{~nm}$ on a spectrophotometer.

\subsubsection{Cellulase activities}

In order to estimate cellulase enzymatic activity, first $1 \mathrm{gm}$ sample was taken. After that $10 \mathrm{~mL}$ of $1 \%$ carboxy methyl cellulose (CMC) was added as substrate followed by $10 \mathrm{~mL}$ of acetate buffer $(0.2 \mathrm{M}$ solution of acetic acid $+0.2 \mathrm{M}$ solution of sodium acetate, $\mathrm{pH}-5.9)$. After that, the solution was incubated for 24 hours and the releasedsugar was estimated by di-nitrosalicylic (DNS) acid method (Miller 1959).

\subsubsection{Laccase activities}

Laccase activity of the samples were done by preparing the crude enzyme extract from moist soil (Songulashvili et al. 2007). First, 10 $\mathrm{ml}$ of distilled water was added to $1 \mathrm{~g}$ of soil and shaken for 30 minutes. After shaking, the samples were filtered and centrifuged at $10000 \mathrm{rpm}$ for $15 \mathrm{~min}$. Then, $25 \mu \mathrm{l}$ of the supernatant was taken and $1.5 \mathrm{~mL}$ of $0.2 \%$ ABTS in sodium acetate buffer was added. It was incubated at $30^{\circ} \mathrm{C}$ for $30 \mathrm{~min}$. After incubation, absorbance was taken at $436 \mathrm{~nm}$ by using spectrophotometer.

\subsubsection{Cellulose, hemicellulose and lignin content}

Ultrasound assisted alkaline extraction method was used for the estimation of cellulose, hemicellulose lignin content of samples collected from straw decomposition. The samples were collected at regular intervals during rice-straw decomposition were dried and grinded into powder. One gram of sample was taken in centrifuge tube. Then samples were treated with $2 \mathrm{M} \mathrm{NaOH}$ solution, and there after it were placed in water bath at $90^{\circ} \mathrm{C}$ for $1.30 \mathrm{hrs}$. Then each tubewas placed in the ultra sonicator for 30 minutes. After sonication, those samples were centrifuged and the residue and filtrate were separated out. Then residue was washed with water for repeated times until clear or transparent filtrate was reached.After washing the tubes were placed in inverted position for $24 \mathrm{hrs}$ and the residues were transferred to petriplates and placed in hot air oven at $50-60^{\circ} \mathrm{C}$ for estimation of cellulose. After the cellulose was 
collected, the filtrate was acidified with $\mathrm{HCl}$ to $\mathrm{pH}$ 5.5. Then it was precipitated with $90 \%$ ethanol solution (1:3:sample:ethanol). It was again centrifuged and residue and filtrate were separated out. Residues were washed with $70 \%$ ethanol solution and after washing the tubes were placed inverted position for $24 \mathrm{hrs}$ and then similar to cellular estimation the residues were transferred to petriplates and placed in hot air oven at $50-60^{\circ} \mathrm{C}$ and hemicellulose content were obtained. Then filtrateswere acidified with $\mathrm{HCl}$ to $\mathrm{pH} 1.5$ and placed for evaporation of ethanol. Samples were centrifuged after evaporation of ethanol. Theresidues were washed with $\mathrm{HCl}(\mathrm{pH} 2.0)$ and lyophilized. After lyophilization, lignin contents wereobtained after weighing of tubes taking empty tube as control.

\subsubsection{Estimation of carbon: nitrogen (C: $N)$ ratio}

Total carbon and nitrogen content were estimated by using the CN Analyzer (Model No. SNC100-IC, Skalar Primacs). The samples were air dried and grinded by using $2 \mathrm{~mm}$ sieve. After that, $0.5 \mathrm{~g}$ of samples were taken in the auto sampler.

\subsubsection{Weight loss}

At the beginning of the composting $600 \mathrm{~g}$ of oven dried rice straw were taken in each pot. After adding constant amount of water in each treatment for moisture maintenance, the weight was measure. At an interval of seven days during composting, the weight loss of the compost was measured.

\subsection{Greenhouse gas (GHGs) fluxes measurement}

The gas samples were collected from different treatments at seven days interval by using plastic funnel chamber (with volume 5306.6 $\mathrm{cm}^{3}$ and area of $0.053 \mathrm{~m}^{2}$ ) fitted with rubber cork at the top. The funnel is air tight with the upper part of the pot (Figure 1). The gas was collected by using $50 \mathrm{ml}$ syringe and measured the $\mathrm{GHGs}$ i.e. methane $\left(\mathrm{CH}_{4}\right)$, carbon dioxide $\left(\mathrm{CO}_{2}\right)$ and nitrous oxide $\left(\mathrm{N}_{2} \mathrm{O}\right)$ in gas chromatograph (GC) (Model no. Trace 1110, Thermo Scientific). This GC was fitted with Porapak Q column and having flame ionization detector (FID) and electron capture detector (ECD) for measuring the GHGs concentrations. The GHGs fluxes were calculated by using this formula (Equations 1, 2,3).

\section{See formulas 1,2 , and 3 in the supplementary files.}

\section{Results}

\subsection{Isolation and identification of efficient lignin decomposing microbial consortium}

\subsubsection{Isolation of microbes from potential sources}

In order to identify lignin decomposing microbial population, culturable bacterial and fungal population was isolated from potential natural sources like, elephant dung, vermicompost, compost, and dead plant bark by using nutrient agar (for bacteria) and potato dextrose agar(for fungi). Bacterial population $\left(10^{-3}\right.$ and $10^{-4}$ dilution) was highest in elephant dung followed by vermicompost > compost > dead plant bark (Table 1). Similarly, fungal population $\left(10^{-2}\right.$ and $10^{-3}$ dilution) was also highest under elephant dung (5.4 and 5.2 Log cfu g ${ }^{-1}$ ) and lowest in dead plant bark (5.1 and 4.9 Log cfu g ${ }^{-1}$ ) (Table 1).

\subsubsection{Screening and efficiency test of lignin degrading microbes}

After screening by using methylene blue, total of 21 bacteria and 9 numbers of fungal isolates were selected. The efficiency tested of lignin decomposing bacterial isolates were estimated by measuring the quantity of glucose through DNS method produced during decomposition process. The sugar production was increased from $1^{\text {st }}$ days of incubation to 7 days and then it was declined. Compared to all the bacterial isolates, LB 18 and LB 8 degraded the lignin more on each days of incubation. The highest sugar was produced by LB $18\left(154.8 \mathrm{~g} \mathrm{ml}^{-1}\right)$ and LB $8\left(149.9 \mathrm{~g} \mathrm{~m} \mathrm{ml}^{-1}\right)$ at the $7^{\text {th }}$ days of incubation (Figure 2a). However, the glucose production of the fungal isolates was increased from initial days of incubation and was observed maximum at $9^{\text {th }}$ days of incubation. Therefore, the most two efficient fungi were selected for further study i.e. LF 3 and LF 9, which produced 171.3 and $147.0 \mu \mathrm{g} \mathrm{ml}{ }^{-1}$ respectively (Figure 2b).

\subsubsection{Morphological characterization of the isolates}


After the conformation test, all the bacterial and fungal isolates were morphologically evaluated (Table 2). The sequences of selected efficient microbial strains were registered to NCBI. The NCBI accession numbers of LB 8, LB 18 and LF 3, LF 9 were MN784664, MN784667 and MK855473, MK855476, respectively.

\subsection{Evaluation of efficient microbial consortium for rice-straw decomposition}

The efficient bacterial (LB 8, LB 18), fungal (LF 3, LF 9) strains and their consortium were tested in net house condition for evaluating their efficacy of decomposition. The efficacy was tested by quantifying the enzymatic activities, weight loss, reduction of lignin content and decrement of $\mathrm{C}: \mathrm{N}$ ratio during the composting.

\subsubsection{Enzymatic activity}

$\beta$-glucosidase activities

The $\beta$-glucosidase activities were increased in the treatments where microbial consortium were used up to $28^{\text {th }}$ days after composting (DAC) and then steadily decreased up to $42^{\text {th }}$ DAC in all the treatments (Figure $3 a$ ). In $28^{\text {th }}$ DAC, the $\beta$-glucosidase activities were ranged from 423.3 to $630.1 \mu \mathrm{g} \mathrm{PNP} \mathrm{g}^{-1} \mathrm{~h}^{-1}$ in the treatments. The higher $\beta$-glucosidase activities were observed under the microbial consortium, LB 18+LF $3\left(290.4 \mu \mathrm{g} \mathrm{PNP} \mathrm{g}^{-1} \mathrm{~h}^{-1}\right)$ followed by LB 8+LF $3\left(280.3 \mu \mathrm{g} \mathrm{PNP} \mathrm{g}{ }^{-1} \mathrm{~h}^{-1}\right)$ than the other treatments.

Cellulase activities

Similar to $\beta$-glucosidase activities, the cellulase activities were higher at $28^{\text {th }}$ DAC and then decreased up to $42^{\text {th }}$ DAC in all the treatments (Figure $3 \mathrm{~b}$ ). The average cellulase activity throughout the decomposition process, was also higher in LB $18+\mathrm{LF} 3(64.7 \mu \mathrm{g}$ glucose $\left.\mathrm{g}^{-1} \mathrm{~h}^{-1}\right)$ followed by LB $8+$ LF $3\left(62.8 \mu \mathrm{g}_{\text {glucose }} \mathrm{g}^{-1} \mathrm{~h}^{-1}\right)$ than the other treatments and least in control (without microbial

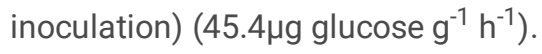

Laccase activities

The laccase activities were ranged from 4.9 to $73.8 \mu_{\mathrm{g} \mathrm{g}}^{-1} \mathrm{~h}^{-1}$ in all the treatments (Figure 3c). Higher laccase activities were observed at $28^{\text {th }}$ DAC followed by $21^{\text {st }}$ DAC. At $28^{\text {th }}$ DAC, higher laccase activities were observed in LF $18+\mathrm{LF} 3\left(73.8 \mu \mathrm{g} \mathrm{g}^{-1} \mathrm{~h}^{-1}\right)$ as compared to

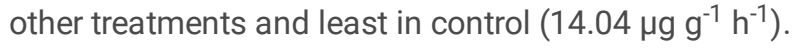

\subsubsection{Cellulose, hemicellulose and lignin content}

The initial content of cellulose, hemicellulose and lignin of the rice straw were $39.4,20.4$ and $9.3 \%$, respectively. After inoculation of microbes and their consortium to the rice straw, the cellulose, hemicellulose and lignin content was decreased significantly to 18.4, 17.8 and $7.2 \%$, respectively at $28^{\text {th }}$ DAC (Figure $\left.4 a, b, c\right)$.

\subsubsection{C: N ratio}

The $\mathrm{C}$ and $\mathrm{N}$ contents were ranged from 45.6 to $52.6 \%$ and 0.71 to $0.82 \%$, respectively at initial date of composting and 31.8 to $36.1 \%$ and 1.27 to $1.42 \%$, respectively at $28^{\text {th }}$ DAC (Table 3 ). Similarly, the C: $\mathrm{N}$ ratio were reduced from initial day of composting (60.0 to $67.3 \%)$ to $28^{\text {th }}$ DAC composting (24.8 to $27.7 \%$ ) in all the treatments. Moreover, highest degree of reduction of C: $\mathrm{N}$ ratio was found at $28^{\text {th }}$ DAC in the consortium LB $18+\mathrm{LF} 3(60 \%)$ as compared to control treatment.

\subsubsection{Weight loss}

Weight reduction were significant from initial to $28^{\text {th }}$ DAC (59.5 to $\left.64.3 \%\right)$ and after wards ( 68.0 to $\left.77.0 \%\right)$ at $42^{\text {nd }}$ DAC. Highest degree of weight reductions (26.8 to $36.1 \%$ ) were found t $28^{\text {th }}$ DAC and higher reductions were observed in LF $8+L F 3(253.1 \%)$ followed by LF $18+$ LF $3(220.4 \%)$ consortium than control (Figure 5).

\subsection{The GHGs fluxes during composting}

The GHGs fluxes were measured during rice straw composting in all the treatments. The $\mathrm{CH}_{4}$ fluxes increased from $7^{\text {th }} \mathrm{DAC}$ to $28^{\text {th }}$ DAC and then decreased (Figure 6a). Maximum $\mathrm{CH}_{4}$ flux was observed at $28^{\text {th }}$ DAC in all the treatments. At $28^{\text {th }}$ DAC, the $\mathrm{CH}_{4}$ flux was 
ranged from 0.11 to $1.36 \mathrm{mg} \mathrm{m}^{-2} \mathrm{~h}^{-1}$. Higher $\mathrm{CH}_{4}$ flux was observed in $\mathrm{LB} 18+\mathrm{LF} 3$ treatment $\left(1.36 \mathrm{mg} \mathrm{m}^{-2} \mathrm{~h}^{-1}\right)$ followed by LB $8+\mathrm{LF} 3$ $\left(1.13 \mathrm{mg} \mathrm{m}^{-2} \mathrm{~h}^{-1}\right)$. Higher $\mathrm{CO}_{2}$ flux was also observed at $28^{\text {th }}$ DAC followed by $14^{\text {th }}$ DAC (Figure $6 \mathrm{~b}$ ). At $14^{\text {th }}$ and $28^{\text {th }} \mathrm{DAC}^{\text {the }} \mathrm{CO}_{2}$ fluxes were in the range of 37.9 to $191.9 \mathrm{mg} \mathrm{m}^{-2} \mathrm{~h}^{-1}$ and 84.5 to $201.4 \mathrm{mg} \mathrm{m}^{-2} \mathrm{~h}^{-1}$, respectively. However, there was no significant differences were observed in $\mathrm{N}_{2} \mathrm{O}$ fluxes (Figure 6c).

\section{Discussion}

Huge amount of lignocellulosic rice straw is generated worldwide have the potential to reuse for bioethanol, biochar and pulp production (Bhattacharyya et al. 2020; Huang and Lo 2019). Lignin is a polymer and high molecular weight that gave it rigidity and resistant against decomposition by different kinds of microorganisms, (Wang et al. 2011). However, lignin at the same time causes hindrance for making compost or the value-added product due to their slower decomposition rate. Therefore, microbial decomposition is a viable option to make use of this resource (rice straw) for better alternatives in eco-friendly manner. White-rot and brown-rot fungi are the well-known for lignin-degradation by generating extracellular oxidative enzymes. White-rot fungi like Ceriporia lacerata, Phanerochaete chrysosporium, Ceriporiopsis subvermispora, Cyathus stercolerus, Pleurotuso streausand Pycnoporus cinnarbarinus have been found effective for decomposing different lingo-cellulosic biomass (Shi et al. 2008). It was reported that, the fungi have higher potential but sometimes natural or extreme environmental conditions and substrate restriction is not suitable for lignin degradation (Sharma et al. 2014). Another school of thought that the bacteria, in particular are better microbes having immense environmental adaptability and biochemical versatility for lignin degradation (Maki et al. 2009; Dini et al. 2018). A variety of bacterial species have been reported to be able to degrade lignin and cellulosic materials such as Bacillus, Pseudomonas and Acintobacteria (Maki et al. 2011); Bacillus, Clostridium (Wang et al. 2011), and Acintobacteria (Woo et al. 2014). So there is a potential to use microbial consortium using both fungi and bacteria for eco-friendly decomposition of rice straw for cleaning up environments and to use the value added end products like, bio-compost, biofuel, lignin for producing dyes, paper pulp and generating silica.

Lignin protects cellulose, hemicelluloses and other cell wall constituents in rice straw for easy decomposition but a few microorganisms can act on complex structure of lignin by secreting extra cellular enzymes. Ligno-cellulolytic fungi have benefits in bioconversion of solid waste as they are filamentous and produce high-volume of spores (Datta et al. 2017). Mixed microbial cultures (bacteria and fungi) have greater effect on substrate accumulation through resistance to environmental contamination and increased enzyme production (de Lima et al. 2016). Compatibility of microbial consortium is another important aspect which influences the distribution, density, association and ecological steadiness of communities (Mishra and Malik 2014; Martínez-Sanz et al. 2014; Vázquez et al. 2015). Thus, a better compatible microbial consortium might have plays an important part for hastening rice straw bioconversion. In our experiment, the lignin degrading bacterial and fungal strains were isolated from the natural sources like, elephant dung, dead plant-bark, vermicomposting pits and compost pits. We got two most efficient bacterial (LB 8, Bacillus cereus; $L B$ 18, Enterobacteriaceae bacterium) and two fungal (LF 3, Penicillium sp.; LF 9, Alternaria alternata) isolates, which was used for rice straw composting. These isolates alone and their consortium were used in rice straw composting. Hence isolation of the lignin degrading microbes from natural lignin reach sources is effective due to higher lignin content. The elephants are herbivorous and their dung is reach in lignin. Similarly, the dead plant bark is slowly degraded by the lignin decomposing microbes. Hence, there is a possibility to find efficient isolates from this lignin reach sources.

Composting of agricultural organic wastes through bio-augmentation of biodegradable microbes is an efficient process (SánchezMonedero et al. 2010; Maeda et al. 2010; Yamamoto et al. 2011; Sharma et al. 2014; Wang et al. 2016). In recent years, social demand for economic and eco-friendly decomposing technology of rice straw have drawn attention of researcher. The sustainable resources for the production of biofuel have also increased interest because of cost effectiveness and readiness in the recent past (Chen and Dou 2016). Among them, agricultural byproducts are the emerging source of renewable and eco-friendly raw materials which provide substitute resource biomass for facilitation of high demanded woody materials (Liu et al. 2013; Chen and Dou 2016). As rice straw is a renewable agricultural residue and rich in nutrients, resources, hence it can also be resolve the future energy requirements (Zuroff and Curtis 2012). Recycling of organic matter through agriculture residues (rice straw) also highly adopted methods (Antil and Raj 2012).

Greenhouse gases emission could also increase with low $\mathrm{C}$ : $\mathrm{N}$ ratio of substrate biomass during this biological composting process (Jiang et al. 2011). Biomass burning is a global phenomenon which responsible towards air pollution in worldwide (Yang et al. 2008). Globally, due to high carbon density, forest burning is the major source and agricultural biomass burning (approximately $2020 \mathrm{Tg}$ ) is reported the second for the carbon loss, emission of GHGs and other air pollutants (Crutzen and Andreae 1990; Andreae et al. 2001;

Page 7/19 
Jain et al. 2014). In that context, compost is a valued source for agricultural soil due to its local availability as a rich source of nutrients (Khaliq et al. 2006). In nature, frequency of bio-conversion of rice straw is slow and it takes more time to composting in natural field micro-flora due to moisture limitation (Brethauer and Studer et al. 2014). Increase use combine-harvester further aggravated the problem of in-situ straw decomposition by spreading the straw all over the field. Many a times these cause field burning of straw on large scale. In those context, ex-situ decomposition of rice straw through lignin degrading microbial inoculation is an effective way to hasten the composting process with ecofriendly manner. The practice of lingo-cellulolytic microorganisms inoculation has been widely used as an worthy approach that could potentially hasten up the decomposition (Zeng et al. 2010; Okeke and Lu 2011) and ultimately improve the quality of compost (Zeng et al. 2009; Wang et al. 2011). Hence, microbial decomposition is an effective, environmentally sound alternative for the recycling of straw (Groyal and Sindhu 2011; Meena et al. 2016).

Carbon sources for energy transformation to microbes during composting, and $\mathrm{CO}_{2}$ emission as by product are the indicators of microbial activity and composting stability (Li et al. 2017). In our study, initially the $\mathrm{CO}_{2}$ emission was more (maximum at $28^{\text {th }}$ DAC followed by $14^{\text {th }} \mathrm{DAC}$ ) and then reduced. The practice of fresh rice straw incorporation to the soil significantly increases methane emissions, whereas decomposed straw emits relatively less emissions (Corton et al. 2000; Bhattacharyya et al. 2012, 2013; Gang et al. 2019).

Inadequate in situ straw decomposition in relation to GHGs emission data comparing with different microbial consortium are available. In addition, emissions from rice straw composting processes should be combined with lignin decomposing enzymatic activities to assess the whole process of composted manures. Similar to $\mathrm{CO}_{2}$, the $\mathrm{CH}_{4}$ fluxes increased from $7^{\text {th }}$ DAC to $28^{\text {th }}$ DAC and then decreased in our study. Applying of rice straw compost in the rice field reduced GHGs emission as compared to straw incorporation and open-field-straw burning (Table 4). As an aerobic process, composting converts organic substrates into a humus-like material which impedes methanogenesis and increases $\mathrm{CH}_{4}$ oxidation (Chen et al. 2010). As the organically generated compost application is gradually decreasing, hence agricultural soil is largely depend upon straw recycling to get rid of straw burning menace and restore soil carbon eventually better soil health. Although burning of straw in the field condition ensures the quick land preparation to subsequent crops and also restricts the nitrogen immobilization menaces during straw decomposition with wider $\mathrm{C} / \mathrm{N}$ ratio, yet incomplete carbon-combustion generates large amounts of GHGs and adversely affects the air quality (Abdel-Rahman et al. 2016; Hussain et al. 2015). Zschornack et al. (2011) indicated that $\mathrm{CH}_{4}$ and $\mathrm{N}_{2} \mathrm{O}$ emission decrease by 69 and $81 \%$, respectively in surface retention when compared to straw incorporation in rice fields (Hussain et al. 2015). Apart from this, open straw burning is an unrestrained combustion practice, in which $\mathrm{CO}_{2}, \mathrm{~N}_{2} \mathrm{O}, \mathrm{CH}_{4}, \mathrm{CO}$, other hydrocarbons ( $\mathrm{NMHC}$ ), $\mathrm{NOx}, \mathrm{SO}_{2}$, particulate matter (PM) were also emitted to the atmosphere. It is estimated that quantity of annual rice straw open burnt $(13.92 \mathrm{Tg})$ in India would represent about $15 \%$ of the total amount of crop residues ( $84 \mathrm{Tg}$ ) (Streets et al. 2003). On the other hand, applying the rice-straw-compost could reduce the $\mathrm{CH}_{4}$ emissions from irrigated paddy fields compared with other fertilizers uses at the same time sustain the yield. Therefore, composting of rice straw by use of efficient lignin degrading microbial consortium is an intelligent step towards mitigating GHGs emission and combat with the menace of straw burning.

\section{Conclusion}

Isolation of lignin decomposing microbial strain from natural sources like elephant dung, dead plant-bark, vermicomposting pits and compost pits found effective for rice straw decomposition in faster time i.e. 28 days. Combination of fungus (LF 3, Penicillium sp.; LF 9, Alternaria alternata) and bacteria (LB 8, Bacillus cereus; LB 18, Enterobacteriaceae bacterium) for hastening ex-situ rice straw decomposition is more effective than single microbial inoculation. Production of $\beta$-glucosidase, cellulase and laccase during decomposition were positively corelated with better quality compost (suitable $\mathrm{C}$ : $\mathrm{N}$ ratio, lignin and cellulose content). However, quicker decomposition relatively triggers higher $\mathrm{CO}_{2}$ and $\mathrm{CH}_{4}$ fluxes, but if we take the process as a whole, it could be balanced. Future endeavor should be in the direction of in-situ straw decomposition in faster time with this valuable microbial consortium in order to curb the menace of on-field straw burning.

\section{Declarations}

Ethics approval and consent to participate: Not applicable

Consent for publication: Not applicable

Page 8/19 
Authors' contributions: P. K. Dash, S. R. Padhy, A. Pattanayak and S. Routray, collected and analyzed the data. P. Bhattacharyya, conceptualized, analyzed, edited and was a major contributor in writing the manuscript. P. Panneerselvam, maintained the microbial culture, A. K. Nayak and H. Pathak, edited and interpreted the manuscript. All authors read and approved the final manuscript.

Funding information: This work was supported by DST Project (EAP-262), ICAR-NRRI-Institute Project-2.7, ICAR-National Fellow Project (Agri. Edn. /27/08/NF/2017-HRD; EAP-248) and NICRA (EAP-245). Authors are grateful to Director of ICAR-National Rice Research Institute (NRRI), for his support and guidance.

Competing interests: The authors declare that they have no competing interests

Availability of data and materials: All data generated or analyzed during this study are included in this published article.

\section{References}

Abdel-Rahman MA, El-Din MN, Refaat BM, Abdel-Shakour EH, Ewais EE, Alrefaey HM (2016) Biotechnological application of thermotolerant cellulose-decomposing bacteria in composting of rice straw. Annals of Agricultural Sciences 61:135-143.

Andersen JK, Boldrin A, Samuelsson J, Christensen TH, Scheutz C (2010) Quantification of greenhouse gas emissions from windrow composting of garden waste. Journal of environmental quality 39: 713-724.

Andreae MO, Merlet P (2001) Emission of trace gases and aerosols from biomass burning. Global biogeochemical cycles 15: 955-966.

Antil RS, Raj D (2012) Chemical and microbiological parameters for the characterization of maturity of composts made from farm and agro-industrial wastes. Archives of Agronomy and Soil Science 58: 833-845.

Bhattacharyya P, Bhaduri D, Adak T, Munda S, Satapathy BS, Dash PK, Padhy SR, Pattanayak A, Routray S, Chakraborti M, Baig MJ (2020) Characterization of rice straw from major cultivars for best alternative industrial uses to cutoff the menace of straw burning. Industrial Crops and Products 143: 111919.

Bhattacharyya P, Nayak AK, Mohanty S, Tripathi R, Shahid M, Kumar A, Raja R, Panda BB, Roy KS, Neogi S, Dash PK (2013) Greenhouse gas emission in relation to labile soil C, N pools and functional microbial diversity as influenced by 39 years long-term fertilizer management in tropical rice. Soil and Tillage Research 129: 93-105.

Bhattacharyya P, Roy KS, Neogi S, Adhya TK, Rao KS, Manna MC (2012) Effects of rice straw and nitrogen fertilization on greenhouse gas emissions and carbon storage in tropical flooded soil planted with rice. Soil and Tillage research 124: 119-130.

Borah AJ, Agarwal M, Poudyal M, Goyal A, Moholkar VS (2016) Mechanistic investigation in ultrasound induced enhancement of enzymatic hydrolysis of invasive biomass species. Bioresource technology 213: 342-349.

Brethauer S, Studer MH (2014) Consolidated bioprocessing of lignocellulose by a microbial consortium. Energy \& Environmental Science 7: 1446-1453.

Chandra R, Raj A, Purohit HJ, Kapley A (2007) Characterization and optimization of three potential aerobic bacterial strains for kraft lignin degradation from pulp paper waste. Chemosphere 67: 839-846.

Chang CH, Liu CC, Tseng PY (2013) Emissions inventory for rice straw open burning in Taiwan based on burned area classification and mapping using FORMOSAT-2 satellite imagery. Aerosol Air Qual Res 13: 474-487.

Chen H, Qiu W (2010) Key technologies for bioethanol production from lignocellulose. Biotechnology advances 28: 556-562.

Chen R, and Dou J (2016) Biofuels and bio-based chemicals from lignocellulose: metabolic engineering strategies in strain development. Biotechnology letters 38: 213-221.

Corton TM, Bajita JB, Grospe FS, Pamplona RR, Assis CA, Wassmann R, Lantin RS, Buendia LV (2000) Methane emission from irrigated and intensively managed rice fields in Central Luzon (Philippines). Nutrient Cycling in Agroecosystems 58: 37-53. 
Crutzen PJ, Andreae MO (1990) Biomass burning in the tropics: Impact on atmospheric chemistry and biogeochemical cycles. Science 250: 1669-1678.

Datta R, Kelkar A, Baraniya D, Molaei A, Moulick A, Meena R, Formanek P (2017) Enzymatic degradation of lignin in soil: A review. Sustainability 9: 1163. https://doi.org/10.3390/su9071163

de Lima Brossi MJ, Jiménez DJ, Cortes-Tolalpa L, van Elsas JD (2016) Soil-derived microbial consortia enriched with different plant biomass reveal distinct players acting in lignocellulose degradation. Microbial ecology 71: 616-627.

Dini IR, Wawan W, Hapsoh H, Sriwahyuni S (2018) Isolation and Identification of Cellulolytic and Lignolytic Bacteria from the Gut Oryctes rhinoceros L. Larvae Decomposition of Oil Palm Empty Fruit Bunches. Indonesian Journal of Agricultural Research 1: 193-203.

Duan Y, Awasthi SK, Liu T, Zhang Z, Awasthi MK (2019) Evaluation of integrated biochar with bacterial consortium on gaseous emissions mitigation and nutrients sequestration during pig manure composting. Bioresource technology 291: 121880.

Eivazi F, Tabatabai MA (1988) Glucosidases and galactosidases in soils. Soil Biology and Biochemistry 20: 601-606.

FAO, what are sustainable rice systems? Food and Agriculture Organization of the United Nations. 2017.

http://www.fao.org/agriculture/crops/thematicsitemap/theme/spi/scpi-home/managing-ecosystems/ sustainable-rice-systems/ricewhat/en.

Gadde B, Bonnet S, Menke C, Garivait S (2009) Air pollutant emissions from rice straw open field burning in India, Thailand and the Philippines. Environmental Pollution 157: 1554-1558.

Gang L, Jing MA, Yuting Y, Haiyang YU, Zhang G, Hua, XU (2019) Effects of Straw Incorporation with a Microbial Inoculant on Nitrous Oxide and Methane Emissions from a Wheat-Rice Rotation System. Pedosphere 29: 204-215.

Garrote G, Domínguez H, Parajó JC (2002) Autohydrolysis of corncob: study of non-isothermal operation for xylo oligosaccharide production. Journal of Food Engineering 52: 211-218.

Groyal S, Sindhu SS (2011) Composting of rice straw using different inocula and analysis of compost quality. Microbiol J 1: 126-138.

Gupta VK, Kubicek CP, Berrin JG, Wilson DW, Couturier M, Berlin A, Edivaldo Filho XF Ezeji T (2016) Fungal enzymes for bio-products from sustainable and waste biomass. Trends in biochemical sciences 41: 633-645.

Howard RL, Abotsi ELJR, Van Rensburg EJ, Howard S (2003) Lignocellulose biotechnology: issues of bioconversion and enzyme production. African Journal of biotechnology 2: 602-619.

Huang YF, Lo SL. Utilization of rice hull and straw. In Rice 2019 Jan 1 (pp. 627-661). AACC International Press.

Hussain S, Peng S, Faha, S, Khaliq A, Huang J, Cui K, Nie L (2015) Rice management interventions to mitigate greenhouse gas emissions: a review. Environmental science and pollution research 22: 3342-3360.

Jain N, Bhatia A, Pathak H (2014) Emission of air pollutants from crop residue burning in India. Aerosol and Air Quality Research 14: 422-430.

Jiang T, Schuchardt F, Li G, Guo R, Zhao Y (2011) Effect of C/N ratio, aeration rate and moisture content on ammonia and greenhouse gas emission during the composting. Journal of Environmental Sciences 23: 1754-1760.

Khaliq A, Abbasi MK, Hussain T (2006) Effects of integrated use of organic and inorganic nutrient sources with effective microorganisms (EM) on seed cotton yield in Pakistan. Bioresource technology 97: 967-972.

Koga N, Tajima R (2011) Assessing energy efficiencies and greenhouse gas emissions under bioethanol-oriented paddy rice production in northern Japan. Journal of environmental management 92: 967-973.

Li S, Song L, Gao X, Jin Y, Liu S, Shen Q, Zou J (2017) Microbial abundances predict methane and nitrous oxide fluxes from a windrow composting system. Frontiers in microbiology 8: 409.

Page $10 / 19$ 
Liu J, Huang C (2013) Biodegradable composites from rice straw and cornstarch adhesives. Advance Journal of Food Science and Technology 5: 41-45.

Maeda K, Toyoda S, Shimojima R, Osada T, Hanajima D, Morioka R, Yoshida N (2010) Source of nitrous oxide emissions during the cow manure composting process as revealed by isotopomer analysis of and amoA abundance in beta proteo-bacterial ammoniaoxidizing bacteria. Appl Environ Microbiol 76: 1555-1562.

Maki M, Leung KT, Qin W (2009) The prospects of cellulase-producing bacteria for the bioconversion of lignocellulosic biomass. International journal of biological sciences 5: 500 .

Maki ML, Broere M, Leung KT, Qin W (2011) Characterization of some efficient cellulase producing bacteria isolated from paper mill sludges and organic fertilizers. International Journal of Biochemistry and Molecular Biology 2: 146.

Martínez-Sanz M, Villano M, Oliveira C, Albuquerque MGE, Majone M, Reis M, Lopez-Rubio A, Lagaron JM (2014) Characterization of polyhydroxy alkanoates synthesized from microbial mixed cultures and of their nano bio composites with bacterial cellulose nano whiskers. New Biotech 31: 364-376.

Meena MD, Joshi PK, Narjary B, Sheoran, P, Jat HS, Chinchmalatpure AR, Yadav RK, Sharma DK (2016) Effects of municipal solid waste compost, rice-straw compost and mineral fertilisers on biological and chemical properties of a saline soil and yields in a mustard-pearl millet cropping system. Soil Research 54: 958-969.

Miller GL (1959) Use of dinitrosalicylic acid reagent for determination of reducing sugar. Analytical chemistry 31: $426-428$.

Mishra A, Malik A (2014) Novel fungal consortium for bioremediation of metals and dyes from mixed waste stream. Bioresource technology 171: 217-226.

Oanh NTK, Ly BT, Tipayarom D, Manandhar BR, Prapat P, Simpson CD, Liu LJS (2011) Characterization of particulate matter emission from open burning of rice straw. Atmospheric Environment 45: 493-502.

Okeke BC, Lu J (2011) Characterization of a defined cellulolytic and xylanolytic bacterial consortium for bioprocessing of cellulose and hemicelluloses. Applied Biochemistry and Biotechnology 163: 869-881.

Rahman NHA, Aziz SA, Hassan MA (2013) Production of ligninolytic enzymes by newly isolated bacteria from palm oil plantation soils. Bioresources 8: 6136-6150.

Rahman NHA, Aziz SA, Hassan MA (2013) Production of ligninolytic enzymes by newly isolated bacteria from palm oil plantation soils. Bioresources 8: 6136-6150.

Romasanta RR, Sander BO, Gaihre YK, Alberto MC, Gummert M, Quilty J, Castalone AG, Balingbing C, Sandro J, Correa Jr T, Wassmann R (2017) How does burning of rice straw affect $\mathrm{CH} 4$ and N2O emissions? A comparative experiment of different on-field straw management practices. Agriculture, ecosystems \& environment 239: 143-153.

Sánchez-Monedero MA, Serramiá N, Civantos CGO, Fernández-Hernández A, Roig A (2010) Greenhouse gas emissions during composting of two-phase olive mill wastes with different agroindustrial by-products. Chemosphere 81: 18-25.

Sasikumar V, Priya V, Shankar CS Sekar SD (2014) Isolation and preliminary screening of lignin degrading microbes. Journal of Academia and Industrial Research 3: 291-294.

Satlewal A, Agrawal R, Bhagia S, Das P, Ragauskas AJ (2018) Rice straw as a feedstock for biofuels: Availability, recalcitrance, and chemical properties. Biofuels, Bioproducts and Biorefining 12: 83-107.

Sharma A, Sharma R, Arora A, Shah R, Singh A, Pranaw K, Nain L (2014) Insights into rapid composting of paddy straw augmented with efficient microorganism consortium. International Journal of Recycling of Organic Waste in Agriculture 3: 54.

Shi J, Chinn MS, Sharma-Shivappa RR (2008) Microbial pretreatment of cottonstalks by solid state cultivation of Phanerochaete chrysosporium. Bioresour Technol 99: 6556-6564. 
Songulashvili G, Elisashvili V, Wasser SP, Nevo E, Hadar Y (2007) Basidiomycetes laccase and manganese peroxidase activity in submerged fermentation of food industry wastes. Enzyme and Microbial Technology 41: 57-61.

Streets DG, Yarber KF, Woo JH, Carmichael GR (2003) Biomass burning in Asia: Annual and seasonal estimates and atmospheric emissions. Global Biogeochemical Cycles 17: 10.

Tipayarom D, Oanh NK (2007) Effects from open rice straw burning emission on air quality in the Bangkok Metropolitan Region. Science Asia 33: 339-345.

Vázquez MA, De La Varga D, Plana R, Soto M (2015) Integrating liquid fraction of pig manure in the composting process for nutrient recovery and water re-use. Journal of Cleaner Production 104: 80-89.

Wang C, Dong D, Wang H, Müller K, Qin Y, Wang H, Wu W (2016) Metagenomic analysis of microbial consortia enriched from compost: new insights into the role of Actinobacteria in lignocellulose decomposition. Biotechnology for biofuels 9: 22.

Wang WD, Yan L, Cui ZJ (2011) Characterization of a microbial consortium capable of degrading lignocelluloses. Bioresour Technol 120: 9321-9324.

Woo HL, Hazen TC, Simmons BA, DeAngelis KM (2014) Enzyme activities of aerobic lignocellulolytic bacteria isolated from wet tropical forest soils. Systematic and applied microbiology 37: 60-67.

Yamamoto N, Asano R, Yoshii H, Otawa K, Nakai Y (2011) Archaeal community dynamics and detection of ammonia-oxidizing archaea during composting of cattle manure using culture-independent DNA analysis. Applied microbiology and biotechnology 90 : 1501-1510.

Yang S, He H, Lu S, Chen D, Zhu J (2008) Quantification of crop residue burning in the field and its influence on ambient air quality in Suqian, China. Atmospheric Environment 42: 1961-1969.

Zeng G, Yu M, Chen Y, Huang D, Zhang J, Huang H, Jiang R, Yu Z (2010) Effects of inoculation with Phanerochaete chrysosporium at various time points on enzyme activities during agricultural waste composting. Bioresource technology 101: 222-227.

Zeng GM, Huang HL, Huang DL, Yuan XZ, Jiang RQ, Yu M, Yu HY, Zhang JC, Wang RY, Liu XL (2009) Effect of inoculating white-rot fungus during different phases on the compost maturity of agricultural wastes. Process Biochemistry 44: 396-400.

Zschornack T, Bayer C, Zanatta JA, Vieira FCB, Anghinoni I (2011) Mitigation of methane and nitrous oxide emissions from floodirrigated rice by no incorporation of winter crop residues into the soil. Revista Brasileira de Ciência do Solo 35: 623-634.

Zuroff TR, Curtis WR (2012) Developing symbiotic consortia for lignocellulosic biofuel production. Applied microbiology and biotechnology 93: 1423-1435.

\section{Tables}

Table 1: Lignin degrading bacteria and fungus population of different lignin reach natural sources.

\begin{tabular}{|c|c|c|c|c|}
\hline \multirow[t]{2}{*}{ Natural sources } & \multicolumn{2}{|c|}{ Bacteria } & \multicolumn{2}{|c|}{ Fungus } \\
\hline & $10^{-3}$ & $10^{-4}$ & $10^{-3}$ & $10^{-4}$ \\
\hline Compost & $5.9 \pm 0.05$ & $5.6 \pm 0.05$ & $5.2 \pm 0.02$ & $5.0 \pm 0.05$ \\
\hline Vermicompost & $6.0 \pm 0.05$ & $5.8 \pm 0.03$ & $5.3 \pm 0.03$ & $5.1 \pm 0.02$ \\
\hline Elephant dung & $6.2 \pm 0.02$ & $6.0 \pm 0.03$ & $5.4 \pm 0.03$ & $5.2 \pm 0.02$ \\
\hline Bark composing soil & $5.6 \pm 0.05$ & $5.3 \pm 0.1$ & $5.1 \pm 0.04$ & $4.9 \pm 0.04$ \\
\hline
\end{tabular}


Table 2: Morphological characterization and NCBI Accession number of the efficient lignin degrading bacterial isolates

\begin{tabular}{|c|c|c|c|c|c|c|c|c|}
\hline \multicolumn{9}{|c|}{ Lignin degrading bacterial isolates } \\
\hline Isolates & Source & Colour & Elevation & Margin & Consistency & Shape & $\begin{array}{l}\text { Accession } \\
\text { number }\end{array}$ & Organism \\
\hline LB 8 & Vermicompost & White & Flat & Entire & $\begin{array}{c}\text { Non } \\
\text { gummy }\end{array}$ & Irregular & MN784664 & Bacillus cereus \\
\hline LB 18 & Elephant dung & White & \multicolumn{2}{|c|}{ Flat } & $\begin{array}{l}\text { Non } \\
\text { gummy }\end{array}$ & Regular & MN784667 & $\begin{array}{c}\text { Enterobacteriaceae } \\
\text { bacterium }\end{array}$ \\
\hline \multicolumn{9}{|c|}{ Lignin degrading fungal isolates } \\
\hline & Isolates & \multicolumn{2}{|c|}{ Source } & Colour & \multicolumn{2}{|c|}{$\begin{array}{c}\text { Accession } \\
\text { number }\end{array}$} & \multicolumn{2}{|r|}{ Organism } \\
\hline & LF 3 & \multicolumn{2}{|c|}{ Compost } & Whitish & \multicolumn{2}{|c|}{ MK855473 } & \multicolumn{2}{|c|}{ Penicillium sp. } \\
\hline & LF 9 & \multicolumn{2}{|c|}{$\begin{array}{l}\text { Dead plant } \\
\text { bark }\end{array}$} & Blackish & \multicolumn{2}{|c|}{ MK855476 } & \multicolumn{2}{|c|}{ Alternaria alternata } \\
\hline
\end{tabular}

Table 3: Carbon, nitrogen content and C: $\mathrm{N}$ ratio during rice straw composting under different treatments. 


\begin{tabular}{|c|c|c|c|c|c|c|c|c|c|c|}
\hline Treatment & DAC & LB 18 & LB 8 & LF 3 & LF 9 & $\begin{array}{c}\text { LB } 18 \\
+ \\
\text { LF } 9\end{array}$ & $\begin{array}{l}\text { LB } 8+ \\
\text { LF } 9\end{array}$ & $\begin{array}{l}\text { LB } 18+ \\
\text { LF } 3\end{array}$ & $\begin{array}{l}\text { LB } 8+ \\
\text { LF } 3\end{array}$ & Control \\
\hline \multirow{8}{*}{$\begin{array}{c}\text { Carbon content } \\
\text { (\%) }\end{array}$} & 0 & $\begin{array}{c}48.2 \pm \\
0.94\end{array}$ & $47.6 \pm$ & $49.5 \pm$ & $\begin{array}{c}45.6 \pm \\
0.89\end{array}$ & $50.4 \pm$ & $52.6 \pm$ & $\begin{array}{c}48.4 \pm \\
0.95\end{array}$ & $\begin{array}{c}46.7 \pm \\
0.92\end{array}$ & $\begin{array}{c}49.8 \pm \\
0.98\end{array}$ \\
\hline & 7 & $\begin{array}{c}46.3 \pm \\
0.91\end{array}$ & $\begin{array}{c}45.8 \pm \\
0.90\end{array}$ & $\begin{array}{c}48.1 \pm \\
0.94\end{array}$ & $\begin{array}{c}43.6 \pm \\
0.85\end{array}$ & $\begin{array}{c}49.3 \pm \\
0.97\end{array}$ & $\begin{array}{c}51.4 \pm \\
1.01\end{array}$ & $\begin{array}{c}47.1 \pm \\
0.92\end{array}$ & $\begin{array}{c}45.2 \pm \\
0.89\end{array}$ & $\begin{array}{c}49.2 \pm \\
0.96\end{array}$ \\
\hline & 14 & $43.7 \pm$ & $42.6 \pm$ & $46.3 \pm$ & $42.4 \pm$ & $45.8 \pm$ & $48.2 \pm$ & $43.3 \pm$ & $42.2 \pm$ & $48.6 \pm$ \\
\hline & & 0.86 & 0.83 & 0.91 & 0.83 & 0.90 & 0.94 & 0.85 & 0.83 & 0.95 \\
\hline & 21 & $\begin{array}{c}39.4 \pm \\
0.77\end{array}$ & $\begin{array}{c}36.7 \pm \\
0.72\end{array}$ & $\begin{array}{c}40.2 \pm \\
0.79\end{array}$ & $\begin{array}{c}36.3 \pm \\
0.71\end{array}$ & $\begin{array}{c}41.7 \pm \\
0.82\end{array}$ & $\begin{array}{c}42.9 \pm \\
0.84\end{array}$ & $\begin{array}{c}37.5 \pm \\
0.73\end{array}$ & $\begin{array}{c}36.4 \pm \\
0.71\end{array}$ & $\begin{array}{c}46.2 \pm \\
0.91\end{array}$ \\
\hline & 28 & $\begin{array}{c}35.4 \pm \\
0.69\end{array}$ & $\begin{array}{c}34.6 \pm \\
0.68\end{array}$ & $\begin{array}{c}35.7 \pm \\
0.70\end{array}$ & $\begin{array}{c}31.8 \pm \\
0.62\end{array}$ & $\begin{array}{c}36.1 \pm \\
0.71\end{array}$ & $\begin{array}{c}39.1 \pm \\
0.77\end{array}$ & $\begin{array}{c}34.8 \pm \\
0.68\end{array}$ & $\begin{array}{c}33.2 \pm \\
0.65\end{array}$ & $\begin{array}{c}45.5 \pm \\
0.89\end{array}$ \\
\hline & 35 & $\begin{array}{c}32.7 \pm \\
0.64\end{array}$ & $\begin{array}{l}31.6 \pm \\
0.62\end{array}$ & $\begin{array}{c}34.7 \pm \\
0.68\end{array}$ & $\begin{array}{c}30.7 \pm \\
0.60\end{array}$ & $\begin{array}{c}33.2 \pm \\
0.65\end{array}$ & $\begin{array}{c}36.4 \pm \\
0.71\end{array}$ & $\begin{array}{c}31.1 \pm \\
0.61\end{array}$ & $\begin{array}{c}31.3 \pm \\
0.61\end{array}$ & $\begin{array}{c}42.8 \pm \\
0.84\end{array}$ \\
\hline & 42 & $\begin{array}{c}31.2 \pm \\
0.61\end{array}$ & $\begin{array}{c}30.6 \pm \\
0.60\end{array}$ & $\begin{array}{c}32.6 \pm \\
0.64\end{array}$ & $\begin{array}{c}29.1 \pm \\
0.57\end{array}$ & $\begin{array}{c}30.6 \pm \\
0.60\end{array}$ & $\begin{array}{c}33.5 \pm \\
0.66\end{array}$ & $\begin{array}{c}29.9 \pm \\
0.59\end{array}$ & $\begin{array}{c}27.4 \pm \\
0.54\end{array}$ & $\begin{array}{c}41.2 \pm \\
0.81\end{array}$ \\
\hline \multirow[t]{7}{*}{$\begin{array}{c}\text { Nitrogen } \\
\text { content (\%) }\end{array}$} & 0 & $\begin{array}{c}0.74 \pm \\
0.01\end{array}$ & $\begin{array}{c}0.71 \pm \\
0.01\end{array}$ & $\begin{array}{c}0.82 \pm \\
0.02\end{array}$ & $\begin{array}{c}0.76 \pm \\
0.01\end{array}$ & $\begin{array}{c}0.82 \pm \\
0.02\end{array}$ & $\begin{array}{c}0.76 \pm \\
0.01\end{array}$ & $\begin{array}{c}0.74 \pm \\
0.01\end{array}$ & $\begin{array}{c}0.75 \pm \\
0.01\end{array}$ & $\begin{array}{c}0.74 \pm \\
0.01\end{array}$ \\
\hline & 7 & $\begin{array}{c}0.82 \pm \\
0.02\end{array}$ & $\begin{array}{c}0.86 \pm \\
0.02\end{array}$ & $\begin{array}{c}0.94 \pm \\
0.02\end{array}$ & $\begin{array}{c}0.84 \pm \\
0.02\end{array}$ & $\begin{array}{c}0.86 \pm \\
0.02\end{array}$ & $\begin{array}{c}0.84 \pm \\
0.02\end{array}$ & $\begin{array}{c}0.87 \pm \\
0.02\end{array}$ & $\begin{array}{c}0.82 \pm \\
0.02\end{array}$ & $\begin{array}{c}0.79 \pm \\
0.02\end{array}$ \\
\hline & 14 & $\begin{array}{c}1.04 \pm \\
0.02\end{array}$ & $\begin{array}{l}1.01 \pm \\
0.02\end{array}$ & $\begin{array}{l}1.12 \pm \\
0.02\end{array}$ & $\begin{array}{l}1.06 \pm \\
0.02\end{array}$ & $\begin{array}{l}1.12 \pm \\
0.02\end{array}$ & $\begin{array}{c}1.06 \pm \\
0.02\end{array}$ & $\begin{array}{c}1.08 \pm \\
0.02\end{array}$ & $\begin{array}{l}1.05 \pm \\
0.02\end{array}$ & $\begin{array}{c}0.82 \pm \\
0.02\end{array}$ \\
\hline & 21 & $\begin{array}{l}1.24 \pm \\
0.02\end{array}$ & $\begin{array}{l}1.18 \pm \\
0.02\end{array}$ & $\begin{array}{c}1.32 \pm \\
0.03\end{array}$ & $\begin{array}{c}1.21 \pm \\
0.02\end{array}$ & $\begin{array}{c}1.37 \\
\pm 0.03\end{array}$ & $\begin{array}{c}1.34 \pm \\
0.03\end{array}$ & $\begin{array}{c}1.24 \pm \\
0.02\end{array}$ & $\begin{array}{c}1.28 \pm \\
0.03\end{array}$ & $\begin{array}{c}0.87 \pm \\
0.02\end{array}$ \\
\hline & 28 & $\begin{array}{c}1.36 \pm \\
0.03\end{array}$ & $\begin{array}{c}1.27 \pm \\
0.02\end{array}$ & $\begin{array}{l}1.39 \pm \\
0.03\end{array}$ & $\begin{array}{c}1.28 \\
\pm 0.03\end{array}$ & $\begin{array}{l}1.42 \pm \\
0.03\end{array}$ & $\begin{array}{l}1.41 \pm \\
0.03\end{array}$ & $\begin{array}{c}1.33 \pm \\
0.03\end{array}$ & $\begin{array}{l}1.32 \pm \\
0.03\end{array}$ & $\begin{array}{c}0.92 \pm \\
0.02\end{array}$ \\
\hline & 35 & $\begin{array}{l}1.48 \pm \\
0.03\end{array}$ & $\begin{array}{c}1.41 \pm \\
0.03\end{array}$ & $\begin{array}{c}1.43 \\
\pm 0.03\end{array}$ & $\begin{array}{c}1.38 \pm \\
0.03\end{array}$ & $\begin{array}{c}1.52 \pm \\
0.03\end{array}$ & $\begin{array}{c}1.47 \pm \\
0.03\end{array}$ & $\begin{array}{c}1.38 \pm \\
0.03\end{array}$ & $\begin{array}{l}1.46 \pm \\
0.03\end{array}$ & $\begin{array}{c}0.98 \pm \\
0.02\end{array}$ \\
\hline & 42 & $\begin{array}{c}1.52 \pm \\
0.03\end{array}$ & $\begin{array}{c}1.47 \pm \\
0.03\end{array}$ & $\begin{array}{c}1.48 \pm \\
0.03\end{array}$ & $\begin{array}{c}1.54 \pm \\
0.03\end{array}$ & $\begin{array}{c}1.61 \pm \\
0.03\end{array}$ & $\begin{array}{c}1.54 \pm \\
0.03\end{array}$ & $\begin{array}{c}1.55 \pm \\
0.03\end{array}$ & $\begin{array}{c}1.56 \pm \\
0.03\end{array}$ & $\begin{array}{c}1.06 \pm \\
0.02\end{array}$ \\
\hline \multirow[t]{7}{*}{ C:N ratio } & 0 & $\begin{array}{c}65.1 \pm \\
1.28\end{array}$ & $\begin{array}{c}67.0 \pm \\
1.31\end{array}$ & $\begin{array}{c}60.4 \pm \\
1.18\end{array}$ & $\begin{array}{c}60.0 \pm \\
1.18\end{array}$ & $\begin{array}{c}61.5 \pm \\
1.20\end{array}$ & $\begin{array}{c}69.2 \pm \\
1.36\end{array}$ & $\begin{array}{c}65.4 \pm \\
1.28\end{array}$ & $\begin{array}{c}62.3 \pm \\
1.22\end{array}$ & $\begin{array}{c}67.3 \pm \\
1.32\end{array}$ \\
\hline & 7 & $\begin{array}{c}56.5 \pm \\
1.11\end{array}$ & $\begin{array}{c}53.3 \pm \\
1.04\end{array}$ & $\begin{array}{l}51.2 \pm \\
1.0\end{array}$ & $\begin{array}{l}51.9 \pm \\
1.02\end{array}$ & $\begin{array}{c}57.3 \pm \\
1.12\end{array}$ & $\begin{array}{c}61.2 \pm \\
1.20\end{array}$ & $\begin{array}{c}54.1 \pm \\
1.06\end{array}$ & $\begin{array}{c}55.1 \pm \\
1.08\end{array}$ & $\begin{array}{c}62.3 \pm \\
1.22\end{array}$ \\
\hline & 14 & $\begin{array}{c}42.0 \pm \\
0.82\end{array}$ & $\begin{array}{c}42.2 \pm \\
0.83\end{array}$ & $\begin{array}{c}41.3 \pm \\
0.81\end{array}$ & $\begin{array}{c}40.0 \pm \\
0.78\end{array}$ & $\begin{array}{c}40.9 \pm \\
0.80\end{array}$ & $\begin{array}{c}45.5 \pm \\
0.89\end{array}$ & $\begin{array}{c}40.1 \pm \\
0.79\end{array}$ & $\begin{array}{c}40.2 \pm \\
0.79\end{array}$ & $\begin{array}{c}59.3 \pm \\
1.16\end{array}$ \\
\hline & 21 & $\begin{array}{c}31.8 \pm \\
0.62\end{array}$ & $\begin{array}{c}31.1 \pm \\
0.61\end{array}$ & $\begin{array}{c}30.5 \pm \\
0.60\end{array}$ & $\begin{array}{c}30.0 \pm \\
0.59\end{array}$ & $\begin{array}{c}30.4 \pm \\
0.60\end{array}$ & $\begin{array}{c}32.0 \pm \\
0.63\end{array}$ & $\begin{array}{c}30.2 \pm \\
0.59\end{array}$ & $\begin{array}{c}28.4 \pm \\
0.56\end{array}$ & $\begin{array}{c}53.1 \pm \\
1.04\end{array}$ \\
\hline & 28 & $\begin{array}{c}26.0 \pm \\
0.51\end{array}$ & $\begin{array}{c}27.2 \pm \\
0.53\end{array}$ & $\begin{array}{c}25.7 \pm \\
0.50\end{array}$ & $\begin{array}{c}24.8 \pm \\
0.49\end{array}$ & $\begin{array}{c}25.4 \pm \\
0.50\end{array}$ & $\begin{array}{c}27.7 \pm \\
0.54\end{array}$ & $\begin{array}{c}26.2 \pm \\
0.51\end{array}$ & $\begin{array}{c}25.2 \pm \\
0.49\end{array}$ & $\begin{array}{c}49.5 \pm \\
0.97\end{array}$ \\
\hline & 35 & $\begin{array}{c}22.1 \pm \\
0.43\end{array}$ & $\begin{array}{c}22.4 \pm \\
0.44\end{array}$ & $\begin{array}{c}24.3 \pm \\
0.48\end{array}$ & $\begin{array}{c}22.3 \pm \\
0.44\end{array}$ & $\begin{array}{c}21.8 \pm \\
0.43\end{array}$ & $\begin{array}{c}24.8 \pm \\
0.49\end{array}$ & $\begin{array}{c}22.5 \pm \\
0.44\end{array}$ & $\begin{array}{c}21.4 \pm \\
0.42\end{array}$ & $\begin{array}{c}43.7 \pm \\
0.86\end{array}$ \\
\hline & 42 & $\begin{array}{l}20.5 \pm \\
0.40\end{array}$ & $\begin{array}{c}20.8 \pm \\
0.41\end{array}$ & $\begin{array}{c}22.0 \pm \\
0.43\end{array}$ & $\begin{array}{c}18.9 \pm \\
0.37\end{array}$ & $\begin{array}{c}19.0 \pm \\
0.37\end{array}$ & $\begin{array}{c}21.8 \pm \\
0.43\end{array}$ & $\begin{array}{c}19.3 \pm \\
0.38\end{array}$ & $\begin{array}{c}17.6 \pm \\
0.34\end{array}$ & $\begin{array}{c}38.9 \pm \\
0.76\end{array}$ \\
\hline
\end{tabular}

Table 4: Comparison GHGs emission from different straw management process. 


\begin{tabular}{|c|c|c|c|c|c|c|c|c|}
\hline \multicolumn{2}{|c|}{ Straw management } & $\begin{array}{c}\text { Seasonal/ Annual/ } \\
\text { days }\end{array}$ & $\mathrm{CH}_{4}$ & $\mathrm{~N}_{2} \mathrm{O}$ & $\mathrm{CO}_{2}$ & $\begin{array}{l}\text { GWP }\left(\mathrm{CO}_{2}\right. \\
\text { equivalent) }\end{array}$ & Unit & References \\
\hline \multirow{5}{*}{\multicolumn{2}{|c|}{$\begin{array}{c}\text { Rice straw } \\
\text { incorporation }\end{array}$}} & Annual & 440 & 0.71 & 2903 & - & $\begin{array}{c}\mathrm{kg} \\
\mathrm{ha}^{-1}\end{array}$ & Liang et al., 2007 \\
\hline & & Annual & 790 & 0.39 & 545 & - & $\begin{array}{c}\mathrm{kg} \\
\mathrm{ha}^{-1}\end{array}$ & $\begin{array}{c}\text { Koga and Tajima, } \\
2011\end{array}$ \\
\hline & & Seasonal & 107.1 & - & - & - & $\begin{array}{c}\mathrm{kg} \\
\mathrm{ha}^{-1}\end{array}$ & Hou et al., 2013 \\
\hline & & Seasonal & 77 & 1.8 & - & - & $\begin{array}{c}\mathrm{kg} \\
\mathrm{ha}^{-1}\end{array}$ & $\begin{array}{l}\text { Romasanta et al., } \\
2017\end{array}$ \\
\hline & & Seasonal & 115.4 & 0.84 & - & - & $\begin{array}{c}\mathrm{kg} \\
\mathrm{ha}^{-1}\end{array}$ & $\begin{array}{c}\text { Bhattacharyya et } \\
\text { al., } 2012\end{array}$ \\
\hline \multicolumn{2}{|c|}{$\begin{array}{l}\text { Rice straw burning } \\
\text { (India) }\end{array}$} & Annual & 16,253 & 0.8 & 13 & - & $\mathrm{Gg}$ & Gadde et al., 2009 \\
\hline \multirow[t]{4}{*}{ Composting } & Rice straw & 90 days & 333 & - & - & - & $\begin{array}{l}\mathrm{mg} \\
\mathrm{g}^{-1}\end{array}$ & $\begin{array}{l}\text { Goyal and Sindhu, } \\
2011\end{array}$ \\
\hline & & 45 days & - & - & - & 83 & $\mathrm{~kg} \mathrm{t}^{-1}$ & Duan et al., 2019 \\
\hline & & 28 days & 37.8 & 2.34 & 8647 & - & $\begin{array}{l}\mathrm{mg} \\
\mathrm{kg}^{-1}\end{array}$ & In this study \\
\hline & $\begin{array}{l}\text { Garden } \\
\text { waste }\end{array}$ & Annual & - & - & - & 3038 & $\mathrm{~kg} \mathrm{t}^{-1}$ & $\begin{array}{c}\text { Andersen et al., } \\
2010\end{array}$ \\
\hline
\end{tabular}

\section{Figures}

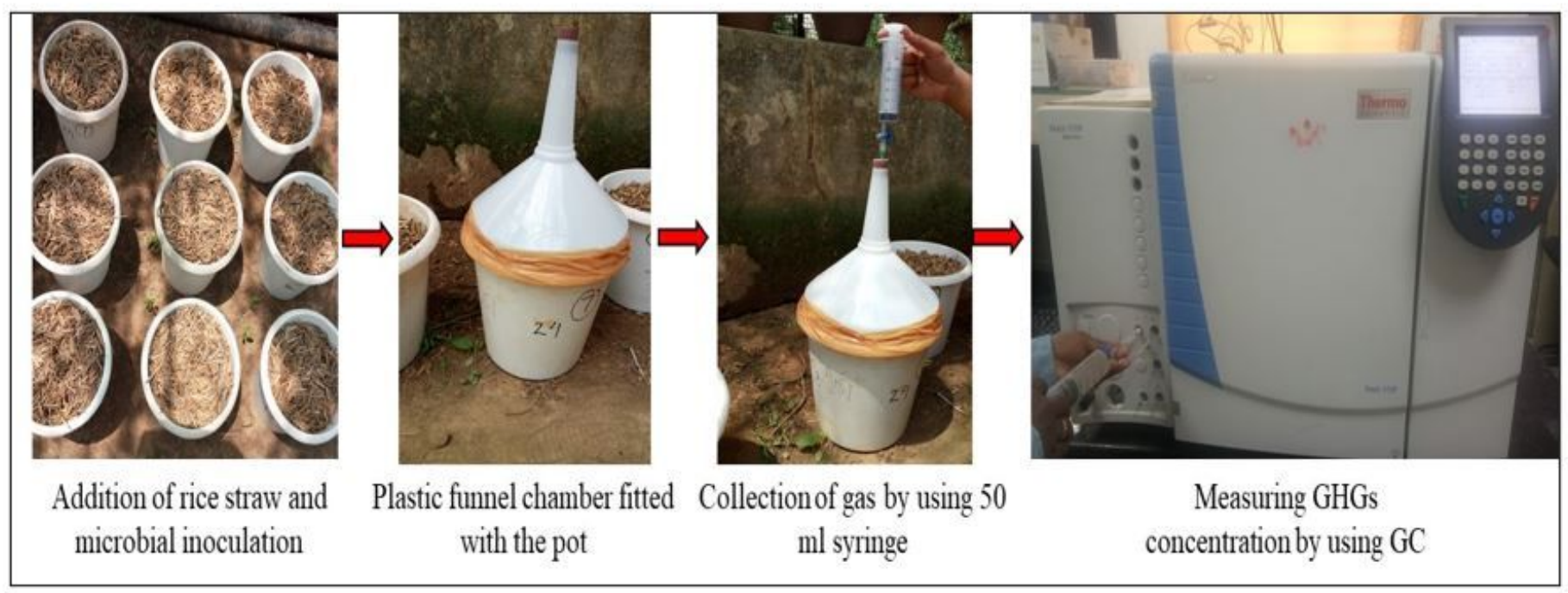

\section{Figure 1}

Greenhouse gas collection and measuring the GHGs concentration during rice straw composting. 

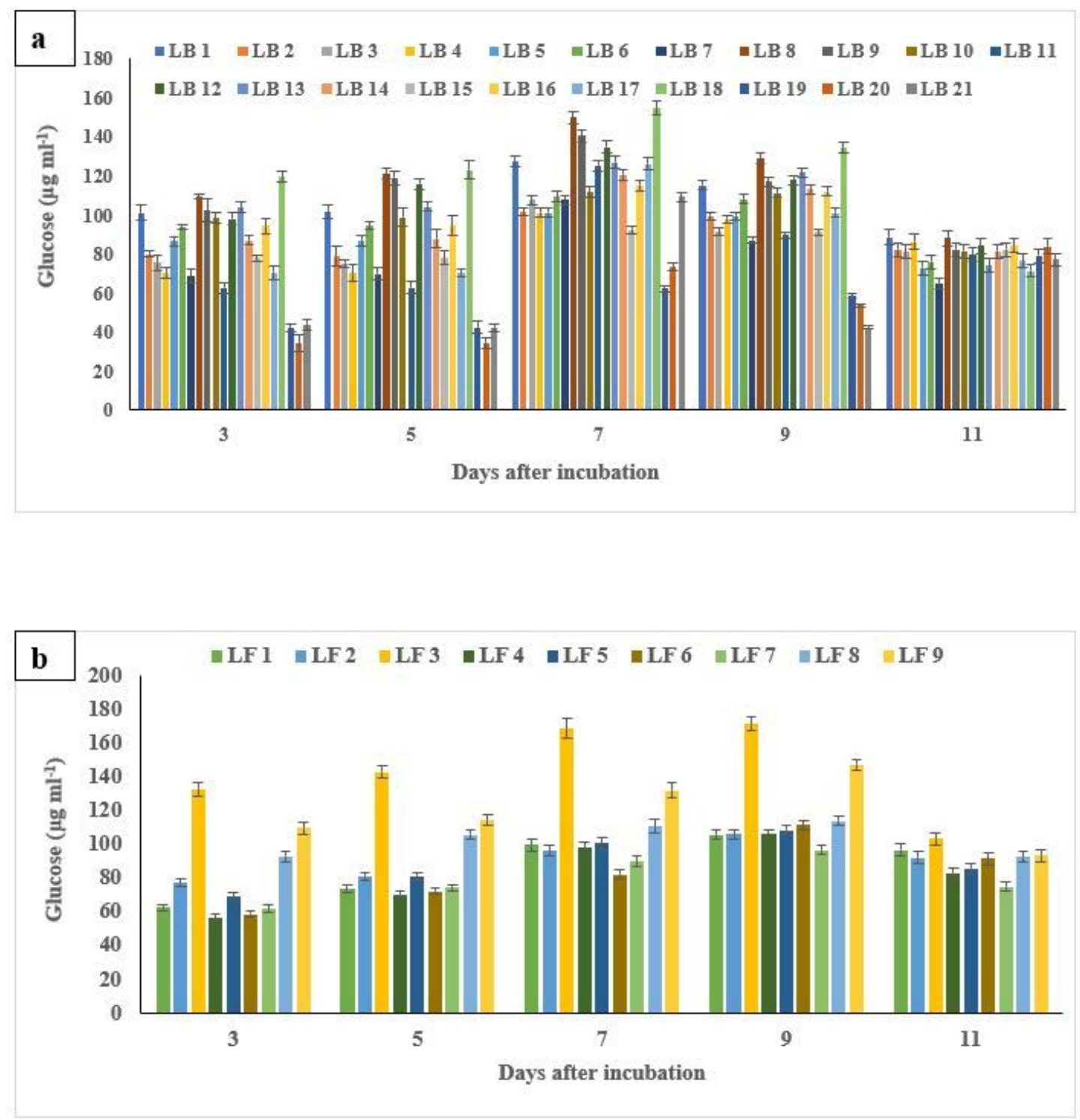

[Note: $\mathrm{LF}=$ lignin degrading fungus; $\mathrm{LB}=$ lignin degrading bacteria]

\section{Figure 2}

Lignin decomposition efficiency test of different (a) bacterial and (b) fungal strains isolated from different lignin reach natural sources. 

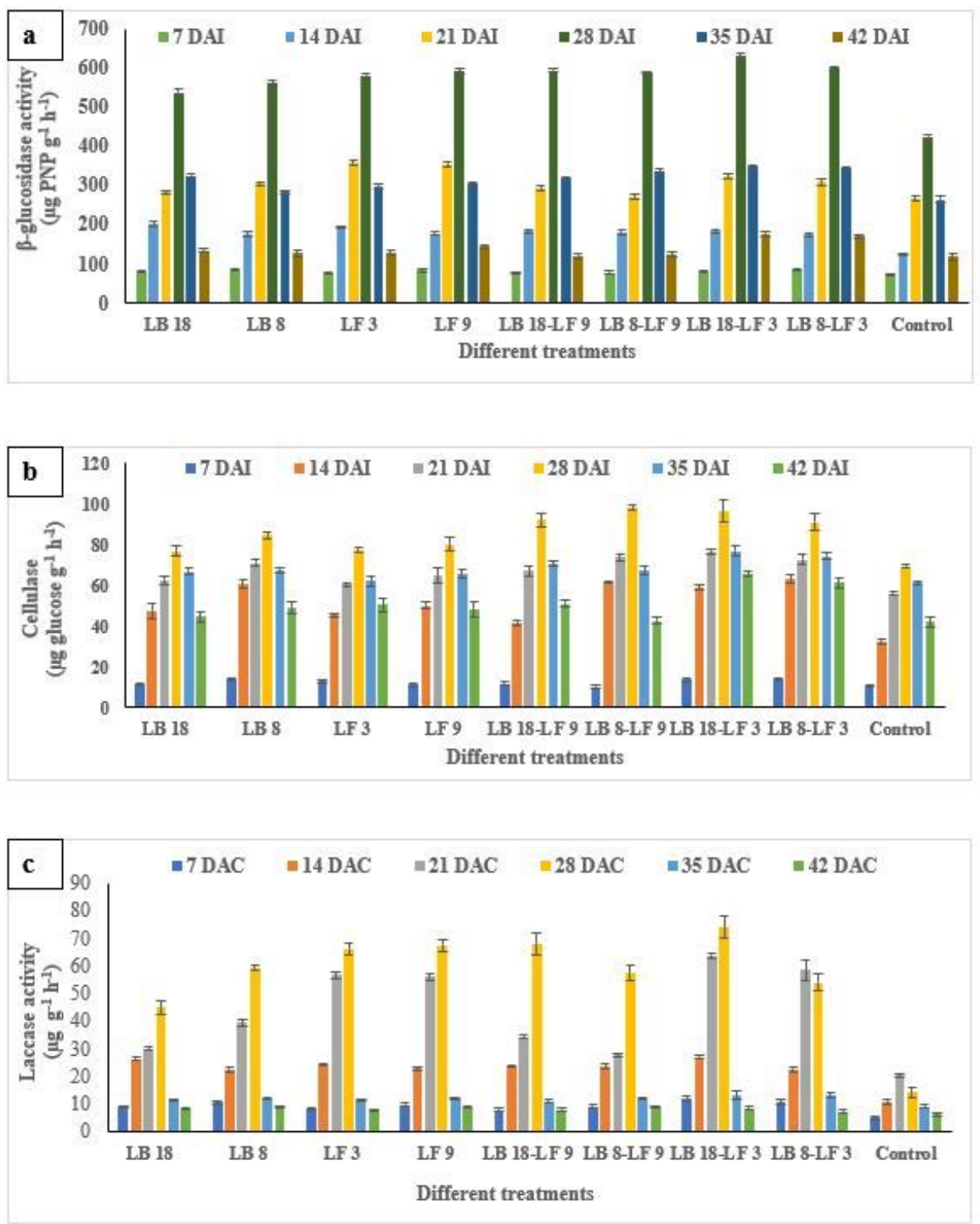

[Note: $\mathrm{LF}=$ lignin degrading fungus; $\mathrm{LB}=$ lignin degrading bacteria; $\mathrm{DAI}=$ date after inoculation]

\section{Figure 3}

(a) $\beta$-glucosidase and (b) cellulase (C) laccase activity of the rice straw at different days after composting (DAC) by using bacterial and fungal strains alone and also their respective consortium. 

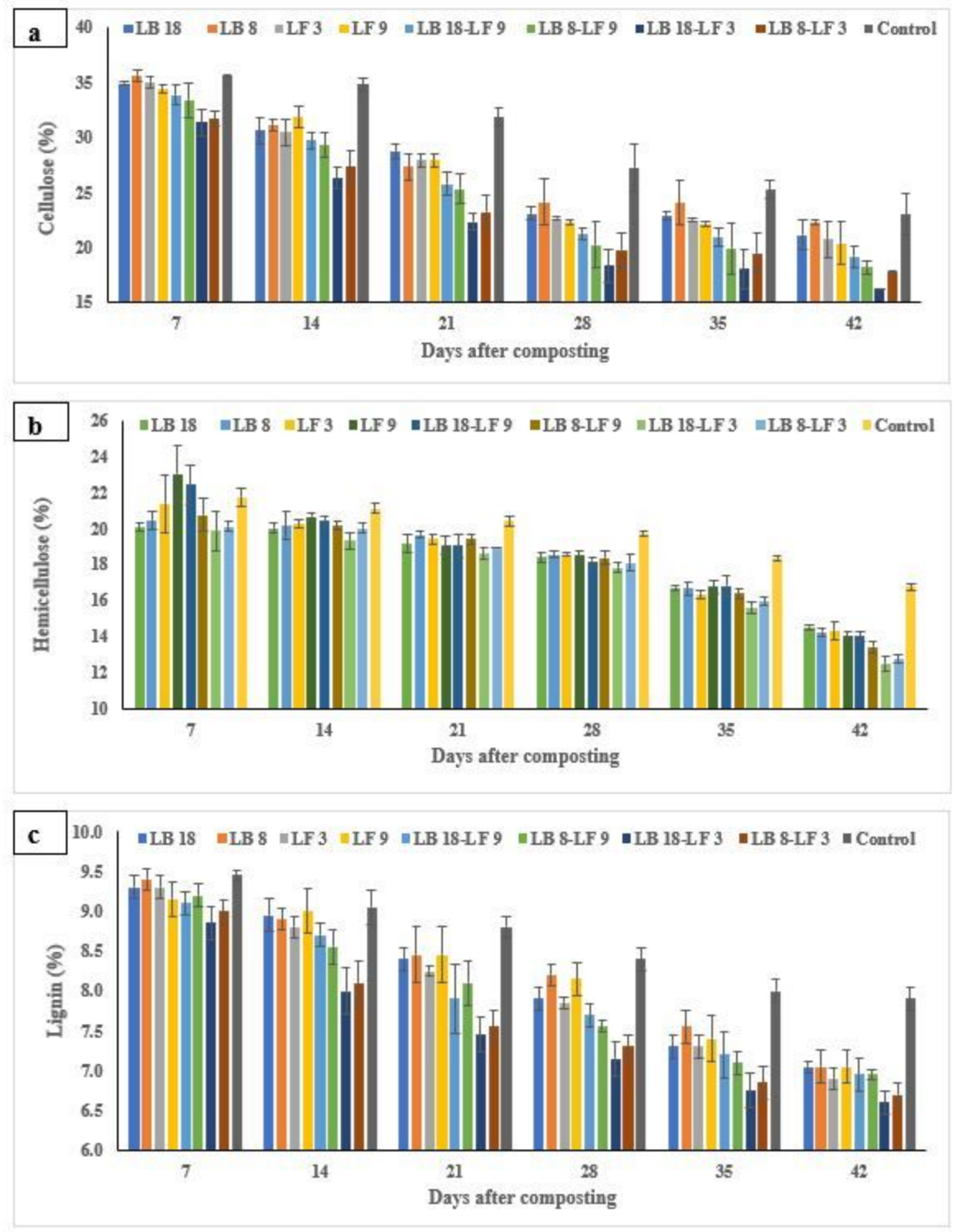

[Note: $\mathrm{LF}=$ lignin degrading fungus; $\mathrm{LB}=$ lignin degrading bacteria]

\section{Figure 4}

(a) cellulose (b) hemicellulose and (c) lignin content of the rice straw at different days after composting (DAC) by using bacterial and fungal strains alone and also their respective consortium.

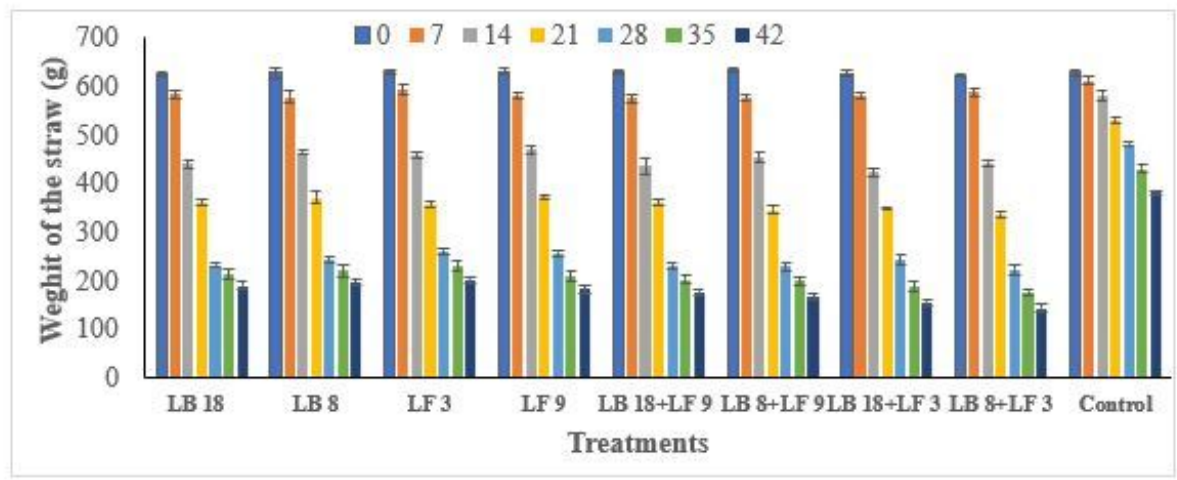

[Note: $\mathrm{LF}=$ lignin degrading fungus; $\mathrm{LB}=$ lignin degrading bacteria]

Figure 5

Page 18/19 
Weight reduction during rice straw composting in all the treatments.
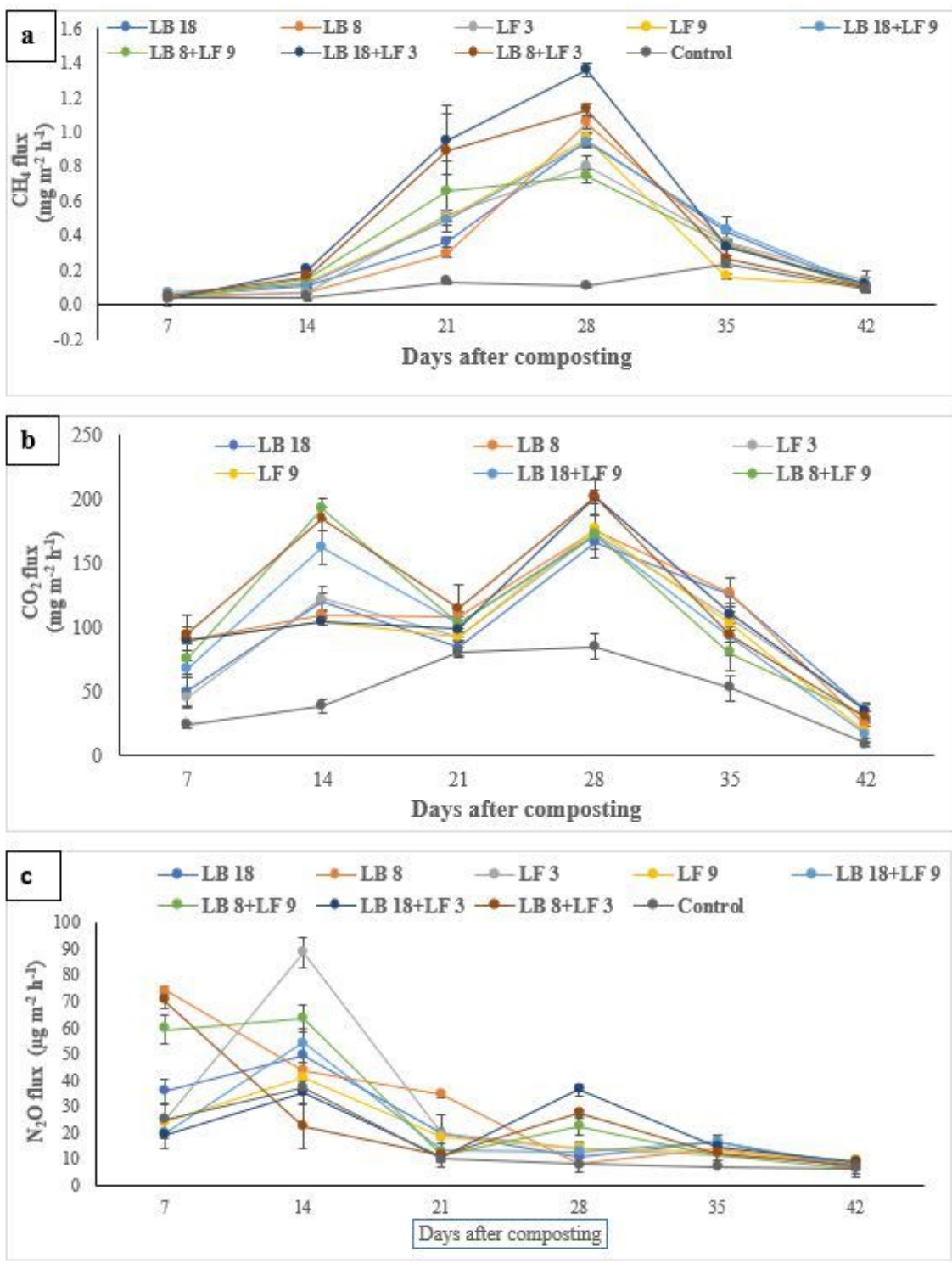

[Note: $\mathrm{LF}=$ lignin degrading fungus; $\mathrm{LB}=$ lignin degrading bacteria]

\section{Figure 6}

(a) Methane ( $\mathrm{CH} 4)$ (b) carbon dioxide (CO2) and (c) nitrous oxide (N2O) flux measurement at different days after composting (DAC) by using bacterial and fungal strains alone and also their respective consortium.

\section{Supplementary Files}

This is a list of supplementary files associated with this preprint. Click to download.

- formulas.docx 